\title{
BREXIT: IS IT REALLY BREAKING FREE? THE IMPLICATIONS OF THE UK'S WITHDRAWAL FROM THE EUROPEAN UNION IN THE FIELD OF COMPETITION
}

\author{
Delphine Defossez*
}

\begin{abstract}
Summary: Globalisation has not only increased international competition but also led to an increasingly more integrated and evolving legal system. On 23 June 2016, 52 percent of British voters opted to leave the European Union in the hope of 'regaining their freedom'. The United Kingdom's decision to leave the European Union has triggered an important political crisis at the same time as raising various questions as to the implications of such a withdrawal. This referendum leaves much uncertainty about the future in many areas, such as competition. Brexit raises particular problems for competition policy and law because of the influence of the European Commission in this field. Indeed, the Commission is the major direct actor, while the national authorities mainly operate within the European framework. Many authors have argued that the implications of the UK's withdrawal from the European Union depend on the type of agreement that is secured by the UK. However, this article argues that whatever the type of agreement the UK strikes with the EU, EU competition law will still play a predominant role.
\end{abstract}

\section{Introduction}

Globalisation has not only increased international competition but has also led to an increasingly more integrated and evolving legal system. The growing similarities between markets, distribution channels, and available infrastructure have enabled companies to sell products and brands all around the world. This facility of access and fluidity of global capital markets has led to increasing vertical and horizontal integration and concentration. ${ }^{1}$

The United Kingdom has been a member of the European Union (EU) since 1973. The UK's dualist approach to international law and the constitutional principle of parliamentary sovereignty required the im-

PhD candidate at the University of Brasilia (UnB), Brazil; LLM at European University Institute; LLM at Swansea University; LLB Maastricht University; https://orcid.org/00000001-7285-0491. DOI: 10.3935/cyelp.14.2018.306.

${ }^{1}$ MR Czinkota, IA Ronkainen, MH Moffett and EO Moynihan, Global Business ( ${ }^{\text {rd }}$ edn, South-Western College Publishers 2001). 
plementation of EU law into national law. ${ }^{2}$ Ever since then, EU law has been an integral part of the UK's legal system, shaping its industry. ${ }^{3}$ As a Member State, the UK benefits from the facilities created by the internal market, such as people and companies being able to sell their goods, labour and services in the other Member States. Up until the referendum decision, the EU had only been expanding. However, on 23 June 2016, 52 percent of British voters, ignoring the experts' warnings of economic misery, opted to leave the Union in the hope of 'regaining their freedom. ${ }^{4}$ The United Kingdom's decision to leave the European Union has triggered a significant political crisis and, at the same time, has raised various questions as to the implications of such a withdrawal. This referendum leaves much uncertainty about the future in many areas, such as competition.

Brexit raises particular problems for competition policy and law because of the influence of the European Commission in this field. Indeed, the Commission is the major direct actor, while the national authorities mainly operate within the European framework.

The implications of the UK's withdrawal from the European Union for competition policy depend on the type of agreement that is secured by the UK. Current UK competition rules are largely modelled on European rules. The UK will probably continue to rely on the Competition Act of 1998 and the Enterprise Act of 2002, even after Brexit. The wish of the UK is to break free from its obligation of conforming with the EU system. Indeed, after Brexit, EU law will no longer be the superior norm and any decisions taken by the EU would no longer be binding upon the UK. At the same time, EU legislation implemented in UK law will still be applied, at least in the short-run, meaning that the UK will not be entirely freed from EU influence.

Brexit raises many questions in the field of competition policy, as the terms on which the UK would leave were not determined by the referendum. A great uncertainty exists with regard to the exact relationship between the EU and the UK that will be implemented after Brexit. Such uncertainty only allows assumptions as to the implications of Brexit for EU and UK competition law. Both EU and UK competition policy and law

\footnotetext{
${ }^{2}$ Graham Gee and Alison L Young, 'Brexit: Regaining Sovereignty?' (2016) 22 European Public Law 131.

${ }^{3}$ Arthur Flieger, 'Newsletter - Flying into the Unknown: The UK's Air Transport Relations with the European Union and Third Countries Following "Brexit" (Part 1)' (Flieger Law Office, 8 May 2018) <www.fliegerlaw.com/en/newsletters/newsletter-flying-into-the-unknown-the-uks-air-transport-relations-with-the-european-union-and-third-countries-following-brexit-part-1-2/> accessed 28 August 2018.

${ }^{4}$ Francesco Capriglione, 'UK Referendum and Brexit Hypothesis: The Wayout Perspective and the Convenience to Remain United' (2016) 27 European Business Law Review 887.
} 
enforcement reflect a consensus that open and competitive markets are the way forward. ${ }^{5}$

This article critically discusses the implications of the UK's withdrawal from the European Union in the field of competition policy, and demonstrates that EU competition law will continue to play an important role, independent of the type of agreement that is concluded between the EU and the UK. To show that EU law will still play a major role, this article will first address the different possible scenarios for exit and then analyse the areas of state aid, antitrust policy and mergers.

\section{Brexit and the different possible scenarios}

After the vote to leave, the UK Government tried to avoid triggering Article 50 of the Treaty on the European Union (TEU). However, the Court of Justice of the European Union (CJEU) and UK courts have ruled that notification under Article 50 cannot be revoked and that the question was not within the prerogative of the CJEU. ${ }^{6}$ The government triggered Article 50 in March 2017, which was, in the general opinion, considered too early due to the lack of a government plan for the future relationship.

Article 50 TEU provides two options for withdrawal from the Union. In the first case, withdrawal enters into force upon agreement. In the second, in the event no agreement is reached, the Member State has two years from the date of notifying the Council. ${ }^{7}$ The withdrawal agreement must be negotiated in accordance with Article 218(3) of the Treaty on the Functioning of the European Union (TFEU). ${ }^{8}$ Interestingly, no timing is given in the Treaty for submitting the notification of exit, but the UK Government has been pressured by both the EU institutions and other Member States to start the procedure for exit to minimise the period of instability. ${ }^{9}$

The nature of the implications of Brexit will depend on the agreement reached between the UK and the EU. This agreement will embody

\footnotetext{
${ }^{5}$ John Vickers, 'Consequences of Brexit for Competition Law and Policy' (2017) 33 Oxford Review of Economic Policy 70.

${ }^{6}$ Steve Peers, 'Brexit: Can the ECJ Get Involved?' (EU Law Analysis, 3 November 2016) available at <http://eulawanalysis.blogspot.com.br/2016/11/brexit-can-ecj-get-involved. html> accessed 24 May 2018.

${ }^{7}$ Art 50(2) and (3) of the Treaty on European Union. Consolidated versions of the Treaty on European Union and the Treaty on the Functioning of the European Union OJ C326, 26 Oct 2012, 1-390.

8 Article 50(2) TEU.

9 Paolo R Vergano and Tobias Dolle, 'The Trade Law Consequences of Brexit' (2016) 7 European Journal of Risk Regulation 795.
} 
a model for future relations between the two. Moreover, the terms of any such agreement will need to be approved by the UK Parliament, the Council and the European Parliament. ${ }^{10}$ In theory, there are several alternative scenarios that could arise following the UK's departure from the EU. As the UK Government pointed out in a report of the House of Commons Foreign Affairs Committee: 'In Europe's current institutional architecture, any decision as to whether the UK should remain in the EU would to a significant extent be a decision about whether the UK should remain in the Single Market'. ${ }^{11}$

\subsection{Scenario 1: bilateral agreements}

Without access to the internal market, the UK would need to enter into a series of bilateral agreements to have access to the internal market under certain conditions, which is often referred to as the Swiss Model. ${ }^{12}$ The extent of such access to the internal market would depend on the UK's willingness to continue applying certain elements of EU law. ${ }^{13}$ However, even in the Swiss example, close cooperation between competition authorities is required, and to this effect, Switzerland signed an agreement with the EU in 2014. ${ }^{14}$ Although this option would enable the UK to keep its sovereignty, it also provides a framework for coordination in the enforcement of competition, and requires a strengthening of cooperation in the fight against breach of competition law. ${ }^{15}$ Moreover, it is probable that industry would put pressure on the UK government to continue applying EU competition law, as the one-stop shop in merger control brings significant benefits to business. Additionally, British companies might encounter difficulties in gaining access to the internal market, as regulatory barriers could limit attractive tariff treatment. ${ }^{16}$ The UK would

\footnotetext{
${ }^{10}$ P Bowers, A Lang, V Miller, B Smith and D Webb, 'Brexit: Some Legal and Constitutional Issues and Alternatives to EU Membership', House of Commons Library Briefing Paper 07214, 2016, 6; Richard Craig, 'UK: The Potential Impact of Brexit on UK Competition Law' (Mondaq, 7 June 2016) <www.mondaq.com/uk/x/498222/Trade+Regulation+Practices/ The+Potential+Impact+Of+Brexit+On+UK+Competition+Law> accessed 24 May 2018.

${ }^{11}$ House of Commons Library, 'Leaving the EU' (Research Paper 13/42, 2013) <http:// researchbriefings.parliament.uk/ResearchBriefing/Summary/RP13-42> accessed 24 May 2017.

12 Ali Nikpay, 'Now What? Competition Law Post-Brexit' [2016] CPI Journal <www.competitionpolicyinternational.com/now-what-competition-law-post-brexit/> accessed 23 May 2018.

${ }^{13}$ Global Counsel, 'Brexit: The Impact on the UK and the EU' (June 2015) <www.global-counsel.co.uk/sites/default/files/special-reports/downloads/Global\%20Counsel_Impact_of_Brexit.pdf> accessed 23 May 2018.

${ }^{14}$ Ovidiu-Horia Maican, 'Legal Aspects of Brexit' (2016) 6 Juridical Tribune 252.

${ }^{15}$ Nikpay (n 12).

${ }^{16}$ Vergano and Dolle (n 9).
} 
probably be required to apply EU regulations to benefit from full access to the internal market. As Paolo R Vergano and Tobias Dolle have noted, 'This requirement would de facto limit British sovereignty'. ${ }^{17}$

To avoid British goods having to be tested twice on safety, health and environmental compliance, an agreement would be necessary between the EU and the UK. Mechanisms to guarantee mutual recognition would, therefore, need to be negotiated. Thus, the freedom that the UK was aspiring to find would not exist with this option, as the situation would pretty much remain the same as before the UK's exit.

The UK could adopt a position identical to the EU-Turkey agreement. ${ }^{18}$ This regime would not guarantee automatic access to the internal market and would only mean that the external tariffs of the UK would be aligned with EU tariffs. Under this approach, the UK would lose control over the applicable tariff but would be able to enter into FTAs with third countries. It would also be able to adopt its own trade defence measures, even against the EU. UK companies would still be subject to EU product standards, however, and in the case of non-compliance, the EU could introduce anti-dumping duties or even suspend the import of UK goods.

Finally, the UK could enter into a 'Deep and Comprehensive FTA', similar to the agreements the EU has with Ukraine or Canada. This type of agreement removes customs duties and restrictions on public procurement and services. It also safeguards intellectual property rights, environmental standards for food safety, workers' protection and technical regulations. Although the UK would not be represented in EU institutions, a forum would be in place to ensure negotiation and discussion. 'With respect to non-tariff barriers on trade in goods, the agreement would apply WTO principles such as national treatment and the prohibition of import and export restrictions. ${ }^{19}$ This approach would not oblige the UK to make any concession on the free movement of persons.

\subsection{Scenario 2: retaining access through an EEA}

Another option could be that the British government and the EU sign a European Economic Area Agreement (EEA). This creates a homogeneous and dynamic agreement, based on equal conditions and common rules of competition. ${ }^{20}$ Moreover - and unlike EFTA, which only al-

\footnotetext{
${ }_{17}$ Vergano and Dolle (n 9).

${ }^{18}$ Decision No 1/95 of the EC-Turkey Association Council on implementing the final phase of the Customs Union (96/142/EC) 22 December 1995.

19 Vergano and Dolle (n 9) 797.

${ }^{20}$ Maican (n 14).
} 
lows free trade with the EU on non-agricultural goods - the EEA enables contracting parties to benefit from the four freedoms: goods, persons, services and capital. The so-called Norway Model provides horizontal provisions relevant to the four freedoms, such as consumer protection. ${ }^{21}$

The EEA agreement also means that two legal systems are applicable in parallel. In the case of trade with EU Member States, UK common law rules would apply, while for mergers, the European Commission would have exclusive jurisdiction. ${ }^{22}$ The exclusive jurisdiction of the Commission means that the one-stop shop for merger control would remain, which is one of the major advantages of this option. This route might be simpler, but it is not straightforward. Indeed, to have EEA membership, the country must first be part of the European Free Trade Area (EFTA).

Joining the EEA would not have a major impact on competition policy in the UK. ${ }^{23}$ Competition is unlikely to be modified in the field of competition and state aid, at least in the short to medium-term. The UK would be required to adopt the competition rules of the EEA Agreement, which is identical in substance to EU rules. ${ }^{24}$ However, the EEA Agreement does not cover a customs union or common trade policy. Therefore, much of the existing body of EU law would still apply, but it would allow the UK to apply its own external tariffs towards third parties. The EEA Agreement also contains prohibitions on abuse of a dominant market position which are similar to EU prohibitions. ${ }^{25}$ The courts of EEA members are also required to interpret EEA provisions in accordance with the decisions of the European courts.

The major disadvantage of this option is that the UK would no longer be able to influence the future developments of EU competition law directly. ${ }^{26}$ Such an impossibility might have implications over the long-term, especially since over the last 20 years the UK has been 'the strongest proponent of competition interventions', focusing exclusively on consum-

\footnotetext{
${ }^{21}$ Vergano and Dolle (n 9).

${ }^{22}$ Georgios Petropoulos, 'Brexit and Competition Policy in Europe' (Breugel, 6 July 2016) $<$ http://bruegel.org/2016/07/brexit-and-competition-policy-in-europe/> accessed 23 May 2018.

${ }^{23}$ Petropoulos (n 22).

24 Jay Modrall and others, 'Antitrust and Competition' (Norton Rose Fulbright, July 2018) <www.nortonrosefulbright.com/knowledge/publications/136988/antitrust-and-competition> accessed 28 August 2018.

${ }^{25}$ Craig (n 10).

${ }^{26}$ Sir Philip Lowe, 'The Implications of Brexit for UK and EU Competition Policy and Law Enforcement: Response to BCLWG October 2016 Issues Paper' (Brexit Competition Law Working Group, 22 November 2016) <www.bclwg.org/wp-content/uploads/2016/11/Response-to-BCLWG-Issues-Paper-PL161116.pdf> accessed 23 May 2018).
} 
er welfare. ${ }^{27}$ Without this direct ability to influence future developments, EU competition law might give more weight to other public policy interests, such as national champions or employment. Such a possibility has been reinforced by the position of François Hollande, the former French president, who, a few days after the referendum, was talking about the adaptation of competition law after Brexit to ensure greater support for growth, employment, and investments. ${ }^{28}$ The UK has mainly been a keen protector of the EU state aid framework and opposed to national champions which demonstrate a more protectionist approach to competition. On top of this, the case law of the CJEU applies to the field covered by the EEA Agreement. This means that the UK would need to comply with EU law without any possibility of voting on such laws.

This option will probably not be chosen after the Prime Minister's speech on 17 January 2017, when it was announced that the UK government was not seeking membership of the single market but was seeking a close trading relationship with the EU through a free trade agreement. ${ }^{29}$ This option was rejected by the Prime Minister because EEA membership defeated the purpose of Brexit, as under this alternative the UK would remain under obligations to apply EU competition law. However, the House of Lords voted for an amendment to the government's Brexit bill which could mean that the UK will adopted this position. The rejection of this model was also motivated by that fact that the relationship between the CMA and the EFTA Surveillance Authority would be quasi-equivalent to the existing relationship between the CMA and the Commission.

As the government's impact assessment has highlighted, this option would result in the smallest damage in terms of the economy. ${ }^{30}$ This scenario would allow the UK to retain full access to the single market without the obligation to sign up for other EU programmes, such as the Common Agricultural Policy. Although the UK would be freed from CJEU jurisdiction, while still required to obey its case law, it would be subject to the EFTA court, which would represent another set of interfering foreign judges. ${ }^{31}$ The greater disadvantage would be that the UK would no longer be able to shape the rules of the single market. The Norway Model

\footnotetext{
27 Nikpay (n 12).

${ }^{28}$ Nikpay (n 12).

${ }^{29}$ Peter Willis and Richard Eccles, 'Brexit: Competition Law Implications' (Bird \& Bird, 26 January 2017) <www.twobirds.com/en/news/articles/2016/uk/competition-law-implications-of-a-brexit> accessed 23 May 2018.

${ }^{30}$ Adam Payne, 'The House of Lords Voted for Theresa May to Negotiate a Norway-style Brexit: Here's What that Means' (Business Insider, 9 May 2018) <www.businessinsider. com/what-is-the-norway-model-brexit-2018-4> accessed 28 August 2018.

${ }^{31}$ Payne (n 30).
} 
is more constraining than the Swiss model, with Norway having signed a wide range of arrangements which cover a broader realm of issues than the ones regulated under the EEA agreement.

\subsection{Scenario 3: no access to the internal market}

The third option is a full exit from the EU without any agreement in place. This would dramatically change the manner in which competition law is applied. At the very beginning of the Brexit negotiations, various EU leaders were resolved to make an example of Brexit by forcing the UK to exit from both the single market and the customs union to show that European integration is an irreversible process. ${ }^{32}$ Indeed, these leaders know that the Union has less to lose than the UK, as $48 \%$ of British exports go to EU countries, compared to $8 \%$ of the EU's exports which head to the UK. ${ }^{33}$ After the first shock of the triggering of Article 50, the EU has demonstrated its willingness to let the UK stay in the single market and customs union if it so wishes, while the UK government was the one insisting on an extreme version of Brexit. One of the possible negative outcomes for the UK is that in its future trade and investment negotiations, it will face less favourable terms. ${ }^{34}$

The picture, however, is not all black and white. Indeed, UK competition law is modelled on the EU system. While Articles 101 and 102 TFEU will no longer directly apply to the UK, it is likely that EU case law would continue to have a strong influence on the way competition law is applied in the UK. At the same time, other provisions would no longer be of any use, such as Article 3 of Regulation 1/2003, the provision preventing national law from prohibiting conduct that is permitted under EU law.

The 1998 Competition Act will need to be amended. For instance, section 60 - which requires the CMA and UK courts to follow EU law - will be abolished. However, other sections are likely to be maintained and copied into domestic law. For example, Section 10, referring to agreements now falling under the EU Block Exemption Regulation and automatically exempted under UK competition law, will no longer be required. Nevertheless, the provisions of the EU Block Exemption Regulation, which are regarded by business and practitioners as beneficial, will need to be kept. It is likely that the provisions will be transcribed into UK law.

${ }^{32}$ Matthias Matthijs, 'Europe After Brexit: A Less Perfect Union' (2017) 96 Foreign Affairs 85.

${ }^{33}$ Matthijs (n 32); House of Commons Library, 'Brexit: Impact Across Policy Areas' (House of Commons Library Briefing Paper No 07213, 26 August 2016) <http://researchbriefings. parliament.uk/ResearchBriefing/Summary/CBP-7213> accessed 23 May 2018.

${ }^{34}$ Matthijs (n 32); House of Commons Library (n 33). 
Merger and antitrust investigations would fall within the competencies of the UK and no longer under the exclusive jurisdiction of the EU, since the EU would no longer be responsible for ensuring the effective operation of competition in the UK. This, in turn, would increase the regulatory costs of business for the UK. Moreover, 'UK lawyers are likely to lose rights of audience before the European courts, and UK lawyers' advice may lose attracting legal privilege in EU proceedings'. ${ }^{35}$ Such advice would no longer be legally privileged in competition cases before the Commission and the Court of Justice. ${ }^{36}$ London is also an important centre for international litigation for damages actions in competition cases. ${ }^{37}$ Following Brexit and without any agreements, Brussels I and Rome II Regulations will no longer apply, significantly reducing the benefits of bringing damages actions in competition cases in London.

Under this situation, the UK could seek to rely on its membership of the World Trade Organization (WTO) as a basis for regulating trade between the EU and itself. ${ }^{38}$ This means that the UK would not have preferential market access to the EU internal market and would not be subject to the EU's common external tariff. Neither would it be subject to the case law of the CJEU. In addition, the UK would not be able to benefit from the FTAs negotiated by the EU and would be obliged to negotiate new ones on its own. The UK would regain absolute customs sovereignty and adopt its own external tariffs, valuations or classifications. UK goods would, however, be subject to the EU external tariffs, as both entities would be able to adopt their own trade defence measures.

\section{Brexit: is it really breaking free?}

Due to the strong trade between the UK and the EU, UK companies will not be able to escape entirely from EU regulations. Indeed, to operate within the internal market, companies will have to comply with EU standards and legislation such as REACH. ${ }^{39}$

\footnotetext{
35 John Schmidt, 'Leave or Remain? What the EU Referendum Means for Competition Lawyers' in Ann-Marie Day and others, Continental Shift: Brexit \& the Law (LexisNexis 2015) 16.

${ }^{36}$ Payne (n 30).

37 Payne (n 30).

${ }^{38}$ Payne (n 30).

${ }^{39}$ Piet Eeckhout, 'Brexit is not an Escape from EU Regulation', (UCL European Institute, 18 February 2016) <www.ucl.ac.uk/european-institute/analysis/2015-16/eu-regulation-brexit> accessed 23 May 2018; Stephen Booth and others, 'What if...? The Consequences, Challenges \& Opportunities Facing Britain outside EU' (Open Europe, March 2015) <http://europas-krisen.zdf.de/media/downloads/Brexit/150507-Open-EuropeWhat-If-Report-Final-Digital-Copy.pdf> accessed 23 May 2018.
} 
Competition policy in both the UK and EU reflects a solid international consensus that competitive and open markets are the most adequate manner of serving consumers. ${ }^{40}$

\subsection{State aid}

State aid refers to any form of advantages conferred to undertakings by national authorities on a selective basis which is incompatible with the internal market. ${ }^{41}$ State aid rules were enacted to control the support that a company can receive from its government, as this advances the company over its competitors. ${ }^{42}$ Therefore, the EU decided to include provisions within the Treaty on the Functioning of the European Union (TFEU) - Articles 107 to 109 - that prohibit state aid 'unless it is justified by reasons of general economic development'. ${ }^{43}$ Provisions on state aid have been in place since the Treaty of Rome, but their content has evolved over time. ${ }^{44}$ These changes have been realised through the amendment of Treaty rules, as well as the enactment of many secondary measures and guidelines, some of which apply to specific sectors, while others apply in a horizontal manner. ${ }^{45}$ Prohibition is not absolute, as in some cases state aid is necessary and fair, but the rules are quite strict. ${ }^{46}$

With a view to ensuring harmonisation, the control of state aid has been delegated to the European Commission. The Commission plays a key role in reviewing aid and deciding whether to alter it or not. The Council, in exceptional circumstances, may block the actions of the Commission by deciding that the aid is compatible with the internal

\footnotetext{
${ }^{40}$ Lowe (n 26).

${ }^{41}$ A broad interpretation has been given to 'aid', to cover all types of transfer of state resources and other economic advantages, including tax exemptions that have an actual or potential effect on trade between Member States. The de minimis rule again applies. Vincent Verouden, 'EU State Aid Control: The Quest for Effectiveness' (2015) 4 European State Aid Law Quarterly 459.

${ }^{42}$ Andrea Biondi, Piet Eeckhout and James Flynn, The Law of State Aid in the European Union (OUP 2004); European Commission, 'State Aid Control' <http://ec.europa.eu/competition/state_aid/overview/index_en.html> accessed 23 May 2018.

${ }^{43}$ European Commission (n 42).

${ }^{44}$ Leigh Hancher, Tom Ottervanger and Pieter J Slot, EU State Aids (Sweet \& Maxwell 2012); Wolfgang Mederer, Nicola Pesaresi and Marc Van Hoof, EU Competition Law: State Aid (Claeys \& Casteels 2008).

45 Individual sectors include: audio-visual productions, broadcasting, electricity, motor vehicles, transport, etc. Horizontal measures are: regional aid, environmental aid, training aid, risk capital aid, etc. See: Herwig CH Hofmann and Claire Micheau, State Aid Law of the European Union (OUP 2016).

${ }^{46}$ Jeremy Lever, 'EU State Aid Law: Not a Pretty Sight' (2013) 1 European State Aid Law Quarterly 5.
} 
market. The EU courts play an important role in the area of state aid. ${ }^{47}$ The General Court is responsible for deciding on direct actions brought by legal or natural persons against the acts of the Commission or other EU institutions. ${ }^{48}$ It also hears complaints about failures to act and regulatory acts, as well as actions brought by Member States against the Commission or Council relating to state aid. The Court of Justice hears appeals from the General Court. ${ }^{49}$

Rules prohibiting Member States from distorting competition by granting aid to specific businesses, which has virtually no equivalent in UK competition law, might be abolished depending on the type of Brexit that is negotiated. ${ }^{50}$ If the UK remains inside the European Economic Area (EEA), the status quo will prevail. ${ }^{51}$ However, if the UK goes for a hard Brexit, the UK would be outside the staid aid control system but would be far from being free, as WTO rules would still apply, since 'virtually no UK-made rules exist at present'. ${ }^{52}$ In theory, the UK would, therefore, have a greater scope for engaging in new industrial strategies by, for instance, giving preferential treatment to UK businesses and subsidising national champions. However, such an approach could have counterproductive effects, since companies in the EU might seek to take punitive measures. In practice, however, it seems that it is not EU rules that have curtailed the government's ability to grant state aid but rather 'the failure of the UK Government to exploit the present rules to the full'. ${ }^{53}$

\footnotetext{
${ }^{47}$ Cormac Little and Claire Waterson, 'The EU State Aid Regime: An Overview' (William Fry 2014) <www.williamfry.com/docs/default-source/2015-pdf/the-eu-state-aid-regime-anoverview.pdf?sfvrsn=0 $>$ accessed 28 August 2018.

${ }^{48}$ Little and Waterson (n 47).

${ }^{49}$ Hofmann and Micheau (n 45); John Temple Lang, 'EU State Aid Rules: The Need for Substantive Reform' (2014) 13(3) European State Aid Law Quarterly 440.

${ }^{50}$ East of England European Partnership, 'Written Evidence (CMP0007)' (13 September 2017) <http://data.parliament.uk/writtenevidence/committeeevidence.svc/evidencedocument/eu-internal-market-subcommittee/brexit-competition/written/69966.html> accessed 8 August 2018; Willis and Eccles (n 29).

${ }^{51}$ Carl Baudenbachen, 'After Brexit: Is the EEA an Option for the United Kingdom?' $\left(42^{\text {nd }}\right.$ Annual Lecture of the Centre for European Law, King's College, London, 13 October 2016) <www.kcl.ac.uk/law/tli/about/Baudenbacher-Kings-College-13-10-16.pdf> accessed 28 August 2018.

${ }^{52}$ East of England European Partnership (no 50).

${ }^{53}$ Select Committee on the European Union Internal Market Sub-Committee, Corrected Oral Evidence: Brexit: Competition (HL 19 October 2017) <http://data.parliament.uk/writtenevidence/committeeevidence.svc/evidencedocument/eu-internal-market-subcommittee/ brexit-competition/oral/71892.html> accessed 8 August 2018; HM Government, 'Review of the Balance of Competences between the United Kingdom and the European Union: Competition and Consumer Policy Report' (2014) <www.gov.uk/government/uploads/system/ uploads/attachment_data/file/332779/Review_of_the_Balance_of_Competences_between_ the_United_Kingdom_and_the_European_Union.pdf> accessed 8 August 2018.
} 
Additionally, the UK will lose influence on the state aid decisions implemented in the EU, which might advantage firms that are also trading in the UK market. ${ }^{54}$ If the UK opts for a trade agreement with the EU, the implications are somewhat less clear. Indeed, in the agreement between Canada and the EU, no provisions on state aid were included, while in the agreement between Ukraine and the EU, Ukraine was required to implement EU rules. ${ }^{55}$

It is the UK government that will take the final decision as to whether to replace the system with a domestic one or not. Nevertheless, it seems quite likely that the EU would insist on a continuation of the equivalent of EEA rules. ${ }^{56}$ A possible solution would be to develop coordination to avoid state aid policies which could distort competition while maintaining a level playing field. This solution would also restrict the possibility of the EU authorities limiting market access to UK companies that have received significant state aid. As already proposed, the CMA could play the role of ensuring compliance with state aid rules. In any event, the WTO anti-subsidy rules would still be applicable and would, therefore, restore part of the EU state aid rules. ${ }^{57}$

\subsection{Antitrust}

The increase in international trade has been promoted by governments and ensured through a set of rules especially developed to increase competitiveness. As a result, antitrust laws have been enacted to promote competition and prohibit market concentration in which a monopoly would emerge.

EU competition law is rooted in the Treaty of Rome of $1958 .{ }^{58}$ Unlike antitrust law in the US, in Europe, the focus has been on preventing abuses of dominant market positions and not preventing structural concentrations of economic power. European policymakers understood the advantages that market concentration creates, and that such concen-

\footnotetext{
${ }^{54}$ Georgios Petropoulos (n 22).

${ }^{55}$ Nicholas Crafts, 'Brexit and State Aid' (2017) 33 Oxford Review of Economic Policy 105, 106.

${ }^{56}$ G Peretz, and K Bacon, 'Paper on Post-Brexit Options for State Aid' (UK State Aid Law Association 2016) <http://uksala.org/paper-on-post-brexit-options-for-state-aid/> accessed 8 August 2018.

${ }^{57}$ Lowe (n 26).

${ }^{58}$ Jürgen Basedow and Wolfgang Wurmnest, Structure and Effects in EU Competition Law: Studies on Exclusionary Conduct and State Aid (Kluwer Law International 2011); Kiran Klaus Patel and Heike Schweitzer (eds), The Historical Foundations of EU Competition Law (OUP 2013).
} 
tration is not dangerous per se..$^{59}$ The abuse of such concentration does, however, interfere with the internal market. ${ }^{60}$ Since the cornerstone idea of the European Union is the internal market, the Union is keen on legislating whenever, in its opinion, certain conduct could have a hindering effect on it, especially as the Union has the powers under Article 3(1)(b) TFEU.

The main legislation in the UK dealing with antitrust matters is the Competition Act of 1998 which brought UK law into line with EU law. The prohibitions of anti-competitive agreements found in Chapter I of the 1998 Act, and of abuse of dominance, found in Chapter II, mirror the prohibitions in Articles 101 and 102 TFEU. Consequently, in all of the scenarios mentioned above, Articles 101 and 102 TFEU will continue to apply post-Brexit both directly to any conduct or agreements by UK businesses having an effect within the EU, and indirectly through reliance on the provision of the Competition Act. On top of this, CJEU judgments might still be referred to as benchmarks for the interpretation of the provisions in Chapters I and II of the Competition Act of 1998, as was the case in Allianz. ${ }^{61}$

Similar to the agreements and conduct of Asian or US companies having an impact on EU markets, a UK business will continue to face investigation and fines by the EU Commission if its conduct affects the internal market. This situation is similar to what happened before Brexit, with the exception that the Commission will no longer be able to carry out on-site investigations in the UK or ask the Competition and Markets Authority (CMA) to do so on its behalf. ${ }^{62}$ The Commission's power will be limited to making written requests for information, as it already does with businesses based outside the EU. ${ }^{63}$

The effects of Brexit will mainly be felt in relation to the enforcement of competition law by the UK authorities. ${ }^{64}$ The pre-Brexit era was highlighted by either the Commission or the CMA claiming exclusive jurisdiction over anti-competitive investigations. The Commission investigated anti-competitive behaviours which affected trade between

\footnotetext{
${ }^{59}$ Sinisa Varga, 'Abuse of a Dominant Market Position in the Frames of the EU Antitrust Law' (2006) 8 Review of European Law 5.

60 Alison Jones and Brenda Sufrin, EU Competition Law: Text, Cases, and Materials (OUP 2016).

${ }^{61}$ Case C-23/11 Allianz Hungária Biztositó Zrt and others v Gazdasági Versenyhivatal ECLI:EU:C:2013:160.

${ }^{62}$ Willis and Eccles (n 29).

${ }^{63}$ Willis and Eccles (n 29).

${ }^{64}$ R Gordon and R Moffatt, 'Brexit: The Immediate Legal Consequences' (Report of the Constitution Society, 2016) <www.consoc.org.uk/wp-content/uploads/2016/05/Brexit-PDF. pdf> accessed 23 May 2018.
} 
Member States, while the CMA only investigated behaviour with an effect restricted to the UK. In the first two scenarios, the enforcement of competition law will not greatly change. However, without agreement, enforcement will be left to the national authority to decide. Due to the role of section 60 of the Competition Act of 1998, even if the section is removed, the impact of it will still be felt. Indeed, the CMA will look at the significant body of case law, which was developed in line with EU law. EU competition case law will, at least at the beginning, remain influential, even without an express statutory link, due to the similarity of the provisions. ${ }^{65}$ One major problem will be that if the UK opts for one of the two first scenarios, since it will no longer have the facility of referring questions for interpretation to the European Court of Justice, it might gradually lead to divergence. The same will be true if the UK does not obtain any agreement.

Moreover, the workload of the CMA will increase, as under EU law national authorities are required to set aside their investigations when the Commission opens a formal investigation. ${ }^{66}$ The risk of parallel investigations will therefore increase. In the post-Brexit era, it will be possible to have an EU cartel investigation running parallel with a UK investigation. Such a possibility endangers business efficiency. On top of that, certain procedural interactions will no longer apply. ${ }^{67}$ For instance, in the pre-Brexit era, cartel members could safeguard their position in the national queues for leniency through a submission of a short form application to the national authority and a full application to the EU authorities.

Section 10 of the 1998 Competition Act will need to be redefined by the government, which may seize the opportunity to enact new exemptions without a strong focus on the single market, as is the case now. ${ }^{68}$ For instance, the government could decide to permit a greater degree of territorial restriction. Due to the strong consensus among businesses and practitioners that the Block Exemption Regulation is beneficial to business, it is likely that the UK will keep the provisions but amend them slightly to reflect the focus of the government.

Directive 2014/104 on antitrust damages actions has not been transposed into UK law and never will be, especially in the case of a hard Brexit. As a result, the UK might become the preferred jurisdiction for bringing competition law damages actions because of the broad disclo-

\footnotetext{
${ }^{65}$ Willis and Eccles (n 29).

${ }^{66}$ Lowe (n 26).

${ }^{67}$ Willis and Eccles (n 29).

${ }^{68}$ Lowe (n 26).
} 
sure available. ${ }^{69}$ In both the Directive and the case law, protection from disclosure of certain documents is provided, including any applications of the defendant for leniency to competition law regulators. ${ }^{70}$ In light of these facts, the UK might become an attractive jurisdiction for claimants but only for companies that are not close to the EU. Indeed, with the decisions of EU institutions no longer binding upon UK courts, any competition judgments will be of no help to the company, as many claims require an infringement decision by the Commission as a proof of the breach, which eliminates a substantial evidential burden for claimants: 'The English court could also bring claims to trial more quickly, without waiting years for the final determination of the cartelists' appeals to the European courts. ${ }^{71}$

The close coordination between the Commission and national competition authorities will be weakened by Brexit. Some of the advantages that the UK had will be lost, which worries airline companies. For instance, almost every area of air transport is affected, from access to the internal aviation market to air traffic management. The future of the UK's air transport relations will depend on the partnership it obtains with the European Union. Indeed, Ryanair, British Airways, and EasyJet might no longer be considered as community air carriers for the purpose of EU Regulation 1008/2008, falling outside of the scope of nearly all the agreements on aviation. This means that these companies will no longer enjoy the competitive advantages that they had up until Brexit, as they will have to comply with two sets of competition rules. These companies will have to relocate their headquarters or sell off a large number of shares to European nationals to avoid losing some major routes within the EU. Moreover, if no agreement is put in place, old bilateral air service agreements will become effective again. ${ }^{72}$ Such agreements will render UK companies less competitive, as they will set capacity requirements, days, the carrier that can operate routes, etc. ${ }^{73} \mathrm{EU}$ competition law ensured fair competition in the liberalised market. ${ }^{74}$

\footnotetext{
${ }^{69}$ Craig (n 10).

${ }^{70}$ Craig (n 10).

${ }^{71}$ Jenny Rayner, 'What does Brexit Mean for Public and Private Enforcement of Competition Law in England and Wales?' (Lexis PSL, 26 July 2016) <www.blplaw.com/media/download/What_does_Brexit_mean_for_public_and_private_enforcement_of_competition_...pdf> accessed 28 August 2018.

${ }^{72}$ B Havel, Beyond Open Skies: A New Regime for International Aviation (Kluwer Law International 2009) 306.

${ }^{73}$ PPC Haanappel, The Law and Policy of Air Space and Outer Space: A Comparative Approach (Kluwer Law International 2003) 114-115.

${ }^{74}$ Civil Aviation Authority, Economic Regulation Group, 'Ownership and Control Liberalisation: A Discussion Paper', (CAP 769, 2006) 16-17.
} 
As suggested by Dr Matthew Cole, a solution would be for the UK to continue to apply antitrust law in the same way but in a 'voluntary' and 'non-binding' manner, allowing courts to develop the law while avoiding departure from the EU system and further burdening companies. ${ }^{75}$

\subsection{Mergers}

'As such, mergers and acquisitions are used not only as a means to achieve market penetration in international markets, but also to achieve greater economies of scope and scale to serve a global customer base more efficiently. ${ }^{76}$ Mergers and acquisitions allow expansion without having to duplicate infrastructure. Currently, nearly every major industry has been consolidated through mergers, such as telecommunications, aviation or financial services. At the same time, mergers and acquisitions remove certain competitors, which can harm the competitive structure of the industry. Moreover, mergers always involve large amounts of money. For this reason, mergers should be controlled to avoid one company owning the market and establishing a monopolistic power. Monopolistic powers enable firms to restrict output.

The majority of jurisdictions require notice of merger. Even though some international organisations have established some level of harmonisation, important discrepancies remain between merger filing regimes. ${ }^{77}$ Surprisingly, no provisions specifically dealing with mergers can be found in the Treaty on the Functioning of the European Union (TFEU) itself or the Treaty on the European Union (TEU). This is because mergers were viewed as a legitimate tool to achieve economic efficiency through economies of scale. ${ }^{78}$ In other words, mergers per se are not problematic. However, when a merger disrupts the internal market, then it is prohibited, as it infringes the prohibition on cartels or abuse of a dominant position in Articles 101, 102, 103 and 106 TFEU. Merger control has a similar role to Article 102 TFEU, but it restricts abuse before concentrations arise. It is an ex-ante prevention of creating dominant firms. The preventive effect was recognised in Gencor Ltd $v$ Commission, ${ }^{79}$ when the

\footnotetext{
${ }^{75}$ Dr Matthew Cole, 'Written Evidence (CMP0040)' <http://data.parliament.uk/writtenevidence/committeeevidence.svc/evidencedocument/eu-internal-market-subcommittee/ brexit-competition/written/70984.html> accessed 8 August 2018.

${ }^{76} \mathrm{KJ}$ Hamner, 'The Globalization of Law: International Merger Control and Competition Law in the United States, The European Union, Latin America and China' (2002) $11 \mathrm{~J}$ Transnational Law \& Policy 385, 388.

${ }^{77}$ François Lévêque and Howard A Shelanski, Merger Remedies in American and European Union Competition Law (Edward Elgar Publishing 2003).

${ }^{78}$ Catalin Stefan Rusu, European Merger Control: The Challenges Raised by Twenty Years of Enforcement Experience (Kluwer Law International 2010).

${ }^{79}$ Case T-102/96 Gencor Ltd $v$ Commission of the European Communities ECLI:EU:T: 1999:65.
} 
Court of First Instance described merger control as being there "to avoid the establishment of market structures which may create or strengthen a dominant position and not ... to control directly possible abuses of dominant positions'. Even so, the regulation of mergers and acquisitions was enacted through secondary legislation, especially the Merger Regulation and the Notices issued by the Commission explaining various aspects of the Merger Regulation. ${ }^{80}$

The first merger regulation was adopted in 1989 and was replaced by the Merger Regulation of 2004, which is based on Article 103 TFEU. The first step towards harmonisation was through Council Regulation $1 / 2003$. The Union wanted to place national courts and national competition authorities at the heart of the procedure under Articles 101 and 102 TFEU ${ }^{81}$ A direct consequence of this EU regulation is that a wide range of mergers involving UK companies falls within the scope of EU merger control rules. ${ }^{82}$

'The Merger Regulation lays down the conditions under which the European Commission or the National Competition Authorities (NCAs) have jurisdiction. ${ }^{83}$ Concentrations with an EU dimension are investigated by the Commission, as it has exclusive jurisdiction, whereas national mergers fall under the jurisdiction of the NCAs according to national merger control rules. The Merger Regulation kept the original thresholds from the 1989 Regulation requiring the prior approval of the Commission specifically for cross-border mergers with an annual turnover of both businesses exceeding EUR 5,000 million worldwide and with EUR 250 million community turnover. ${ }^{84}$ However, to have a European dimension, the two-thirds rule can also play a role, as it is considered that such a dimension is lacking if each of the undertakings concerned achieved more than two-thirds of its EU-wide turnover in one Member State (Article 3) ${ }^{85}$ However, a procedure has been put in place in Article

\footnotetext{
${ }_{80}$ Ioannis Kokkoris and Howard Shelanski, EU Merger Control: An Economic and Legal Analysis (OUP 2014); Greg Olsen, 'Revised EU Merger Remedy Guidance' (2009) 23 Antitrust 80; Lowe (n 26).

${ }^{81}$ Edurne Navarro Varona, Merger Control in the European Union: Law, Economics and Practice (OUP 2005).

82 Jay Modrall and others (n 24).

${ }^{83}$ Slaughter and May, 'The EU Merger Regulation: An Overview of the European Merger Control Rules' (January 2018) 1 <www.slaughterandmay.com/media/64572/the-eu-merger-regulation.pdf> accessed 28 August 2018.

${ }^{84}$ Council Regulation (EC) No 139/2004 of 20 January 2004 on the control of concentrations between undertakings (the EC Merger Regulation) [2004] OJ L24/1, Article 2.

${ }^{85}$ EC Merger Regulation (n 84) Article 3(a) and (b). Deals that do not meet the original thresholds can nevertheless have a European dimension if the combined worldwide turnover of all the undertakings concerned is more than EUR 2,500 million or if each of at least two of the undertakings has an EU-wide turnover of more than EUR 100 million. See Slaughter and May (n 83).
} 
4(4) and (5) as a way of exception under which parties can engage in pre-notification contacts with the authorities with a view to reallocating jurisdiction between the Commission and the NCAs to protect certain national interests. ${ }^{86}$ The Commission must mandatorily be notified, and the merger cannot be implemented unless and until the Commission gives its clearance. The form to be filled in is included in the Implementing Regulation. ${ }^{87}$ No mergers have been assessed by both regulators at the same time. This one-stop shop, as operated by EU mergers, will disappear in the UK in the event of a full Brexit.

With a full Brexit, this exclusive power to assess will no longer exist, meaning that mergers which meet both UK and EU thresholds will be subject to double scrutiny. ${ }^{88}$ This not only increases the risk of conflicting decisions but also substantially increases the costs and burden for companies. ${ }^{89}$ At the same time, it increases the workload of the CMA, which will have jurisdiction over much larger mergers than it did under EU law. ${ }^{90}$ Moreover, the argument that the UK would be able to better defend its firms after Brexit is partially inaccurate. As the CLLS Competition Law Committee has noted, under the EU framework, the UK already has a 'relatively broad scope' to review public interest considerations, and Brexit will only provide opportunities to control mergers in a small number of cases that do not fall within the pre-defined categories, and where additional 'legitimate interest' is not accepted. ${ }^{91}$

If the UK becomes a member of the EEA following Brexit, the implications for competition policy regarding mergers will be minimal, while EU influence will remain visible because the main instrument on mergers and markets, the Enterprise Act of 2002, was modelled on EU law.

For companies, the option of a full Brexit would have disastrous effects. Indeed, nowadays, having a sound knowledge of the thresholds and intricacies of the merger control regime when dealing with complex cross-border mergers and acquisitions is of great importance. Merger re-

\footnotetext{
${ }^{86}$ Slaughter and May (n 83).

87 Commission Regulation (EC) No 802/2004 of 7 April 2004 implementing Council Regulation (EC) No 139/2004 on the control of concentrations between undertakings, OJ 2004 L $133 / 1$.

${ }^{88}$ Norton Rose Fulbright, 'Impact of Brexit on Antitrust and Competition' (Norton Rose Fulbright, 16 July 2016) <www.nortonrosefulbright.com/files/impact-of-a-brexit-on-antitrust-and-competition-137549.pdf> accessed 23 May 2018.

${ }^{89}$ Craig (n 10).

${ }^{90}$ Lowe (n 26); Willis and Eccles (n 29).

${ }^{91}$ Competition Law Committee of City of London Law Society, 'Written Evidence (CMP0017)' <http://data.parliament.uk/writtenevidence/committeeevidence.svc/evidencedocument/ eu-internal-market-subcommittee/brexit-competition/written/70151.html> accessed 9 August 2018.
} 
gimes around the world have proliferated, adding a layer of complexity to international mergers and acquisitions. Most big merger and acquisition transactions have a significant cross-border dimension, meaning wide-ranging regulatory implications. Companies are obliged to notify competition authorities in multiple jurisdictions, including distant locations where neither the bidder nor the target market has operations but where the merger could have an effect, even if the merger occurs between two companies in the same country. For instance, the Boeing/McDonnell Douglas case, ${ }^{92}$ which was the first case in which the European Union refused a merger, even though both companies were incorporated in the US, was refused on the grounds that such a merger would impair the international market. ${ }^{93}$ Consequently, in light of the Douglas case, it seems that a one-stop shop facilitates businesses' operations. A single authority, aside from saving time and diminishing the cost burden of the requirement of clearance in every country where the parties operate, avoids companies constantly needing to check and deal with new merger filing regimes. The end of the 'one-stop shop' for mergers will mean that the work of the UK's Competition and Markets Authority could increase sharply, which could weaken UK competition policy. ${ }^{94}$ Therefore, it would be important to maintain the 'one-stop shop' for merger control through an agreement, but this would depend on the willingness of both parties.

\section{Conclusion}

There is much uncertainty as to the terms of the exit of the UK. The only certainty is that the final date of exit will be in 2019. The full impact of Brexit in the field of competition will require more time to emerge. One immediate risk is the inefficiency through parallel investigations, which could lead to inconsistent outcomes but also increase the burden on businesses. EU competition case law is likely to remain highly influential, at least in practice, because the two major pieces of legislation on competition, the Competition Act of 1998 and the Enterprise Act of 2002, have been modelled on EU competition law. Moreover, even before its accession to the EU, the UK had started to follow EU law. The exit of the UK is likely to force its authorities to set up a new parallel competition regime, at least in the long-run.

\footnotetext{
${ }^{92}$ Case No IV/M877 - Boeing/McDonnell Douglas Council Regulation (EEC) No 4064/89, C(97) 2598 final.

${ }^{93}$ E Stock, 'Explaining the Differing US and EU Positions on the Boeing/McDonnell-Douglas Merger: Avoiding Another Near-Miss' (1999) 20 University of Pennsylvania Journal of International Law 825, 906.

${ }^{94}$ John Fingleton and others, 'The Implications of Brexit for UK Competition Law and Policy' (2017) 13 Journal of Competition Law and Economics 389.
} 
The main rules on competition, namely the prohibitions on agreements and abuse of dominant market positions, are unlikely to change, irrespective of the model adopted. Over the past two decades, international convergence, both within Europe and globally, has increased, with many EU standards becoming global standards, which could result in the indirect influence of EU law on UK law. Consequently, the points of convergence between EU and UK policies would follow the broad consensus on three crucial elements: the prevention of anti-competitive mergers, the prevention of abuse of dominant positions, and anti-competitive agreements. However, views may differ as to what these terms imply. For instance, when looking at a merger, the CMA and the EU Commission will be looking at different geographical markets, leading to potential divergent outcomes. The principal points of divergence will be the remedies provided in the case of mergers and the wider scope to apply non-competition criteria to mergers. Finally, Article 60 of the Competition Act of 1998 will need to be amended because it currently requires consistency with EU jurisprudence and would allow a non-UK court to determine the meaning of a domestic statute.

The exit strategy which will have the greatest impact on UK competition policy is the withdrawal of the UK from the EU without applying for EEA membership. ${ }^{95}$ The UK will be freed from all treaty obligations and compliance with EU law. However, going down this road will mean that the UK loses some of its advantages and that Articles 101 and 102 TFEU will still indirectly apply to conduct by UK businesses affecting the internal market. Thus, UK companies will remain subject to EU competition law, even if the UK adopts a new set of rules. The UK will no longer be bound by EU regulations, which raises questions about the EU Block Exemptions Regulation, whose advantages are widely accepted among practitioners and businesses. In the long-term, the UK position might deviate substantially from the EU approach, as the CMA has rarely investigated such restrictions. A hard Brexit would mean that UK companies will no longer be able to be present in the internal market on a cross-border or branch basis and vice versa.

In highly international and regulated sectors like aviation, Brexit means an enormous potential loss and harsher competition. In the short-term, UK competition law will still apply EU law as UK competition law, which is largely a copy of the key elements of the TFEU. Moreover, the case law in the UK has been influenced by EU law since it joined the EU. It remains to be seen whether the government, in the event of a full Brexit, would change these rules all at once or would only change the focus of the rules. Indeed, with UK courts no longer required to follow the

${ }_{95}$ Craig (n 10). 
decisions of European Courts, it will slowly lead to divergent interpretations between the two regimes.

Another possibility is for the UK to agree to still observe EU law through a bilateral agreement with the EU, using the Swiss model. This model means that the UK would still comply with certain EU laws. This route would allow the UK to develop its own system of competition law without too many constraints from the EU. ${ }^{96}$ However, it is also an extremely complex route which would depend on the UK's negotiating position. Moreover, it would increase bureaucratic and administrative expenses, especially for certain branches, and could be subject to higher fluctuations in foreign exchange rates, which would increase competition pressure.

The final alternative is that the UK will want to retain access to the internal market by becoming a member of the EEA. This would be the simplest option, although rejected by the Prime Minister in a speech in January 2017. This route might be simpler, but it is not straightforward. Indeed, to have EEA membership, the country must first be part of the European Free Trade Area (EFTA). Under this alternative, the UK would remain under the obligation to apply EU competition law. The EEA Agreement also contains similar prohibitions on the abuse of a dominant market position. The courts of the members are also required to interpret EEA provisions in accordance with the decisions of the European courts. ${ }^{97}$ The relationship between the CMA and the EFTA Surveillance Authority would be quasi-equivalent to the existing relationship between the CMA and the Commission. The main advantage of this option is that it allows the UK to retain the benefits flowing from the one-stop shop for merger control. The Norway model might, however, be the best alternative, even with its downsides, and would turn the UK into a pure rule-taker.

Georgios Petropoulos noted that if the UK leaves the EU without any agreement in place, this could change the way that competition law is applied. It could also make antitrust cases more costly and competition policy instruments less effective. ${ }^{98}$ Indeed, the UK is regarded as having one of the most comprehensive competition frameworks and is influential on competition regimes around the world. By leaving the EU, the reputation of UK competition law might suffer. EU competition law will, in one way or another, still influence UK competition law, but the UK will lose its ability to influence EU competition law, to the detriment of its consumers.

\footnotetext{
${ }_{96}$ Craig (n 10).

${ }^{97}$ Craig (n 10).

98 Petropoulos (n 22).
} 